\title{
Evaluation of Toxic Effects with Transition Metal Ions, EDTA, SBTI and Acrylic Polymers on Aedes aegypti (L., 1762) (Culicidae) and Artemia salina (Artemidae)
}

\author{
Eduardo José de Arruda ${ }^{1 *}$, Ana Paula Leão Rossi ${ }^{2}$, Karla Rejane de Andrade Porto ${ }^{2}$, \\ Lincoln Carlos Silva de Oliveira ${ }^{1}$, Andrea Haruko Arakaki ${ }^{3}$, Gessiel Newton Scheidt ${ }^{4}$ and \\ Antonia Railda Roel ${ }^{2}$ \\ ${ }^{1}$ Departamento de Química; Universidade Federal da Grande Dourados; 79804-970, Dourados - MS - Brasil. \\ ${ }^{2}$ Programa de Pós Graduação em Biotecnologia; Universidade Católica Dom Bosco; 79117-900; Campo Grande - \\ MS - Brasil. ${ }^{3}$ Engenharia de Bioprocessos e Biotecnologia; Departamento de Engenharia Química; Universidade \\ Federal do Paraná; Centro Politécnico; 81531-970; Curitiba - PR - Brasil. ${ }^{4}$ Engenharia de Bioprocessos e \\ Biotecnologia; Universidade Federal do Tocantins; 77402-970; Gurupi - TO - Brasil
}

\begin{abstract}
This work aimed to evaluate the toxicity of some insecticides compounds on Aedes aegypti and Artemia salina larvae. Bioassays were carried out to evaluate the toxic effect after of 24 and $72 h$ using the compounds or associations. The $L C_{10}, L C_{50}$ and $L C_{90}$ values were obtained and utilized for toxicity comparations. For Ae. aegypti, $L_{50}$ were $32.65 \mathrm{mg} \mathrm{L}^{-1}$ in $24 \mathrm{~h}$ for $\mathrm{Na}_{2}[\mathrm{EDTA}-\mathrm{Cu}(\mathrm{II})]$ and total mortality in $72 \mathrm{~h}$ for SAP-Na $[\mathrm{EDTA}-\mathrm{Cu}(\mathrm{II})]$.
\end{abstract}

Key words: Dengue fever, Insect control, Lethal Concentration

\section{INTRODUCTION}

Dengue fever, yellow fever and dengue hemorrhagic fever are virus infectious diseases transmitted to humans by the mosquito Aedes aegypti, and is a public health problem of great concern in tropical and subtropical areas (WHO 2008; WHO 2007a; WHO 2007b). According to a report from the World Health Organization about 1.3 billion people are under the risk of being affected by these diseases (WHO 1997; 2006). Ae. aegypti is the most important vector of the four virus serotypes DENV - 1 to 4 involved in dengue fever outbreaks in tropical region (WHO 2004). Despite the progress achieved in reducing the spread of the disease and in eliminating the vectors, the outbreaks are still frequent in urban areas. Besides the uncontrolled urbanization and concurrent population growth, the outbreaks are mostly caused by factors related to the mosquito's biology, behavior and climate change (WHO 2004; WHO 2007b). Primary prevention of dengue mainly resides in eliminating or reducing the mosquito using synthetic pesticides such as Temephós, Malathion, or Fenitrothion and others. However, this ongoing strategy of control has shown an increase in resistant mosquitoes (WHO 2001). Due to the gravity of the epidemic outbreaks year after year, studies have been developed to identify natural and/or chemical

*Author for correspondence: ejarruda@gmail.com 
actives compounds and/or microorganism to formulate more effective products for the human being and environmental security (Autran et al. 2008; Sá et al. 2008; de Omena et al. 2007).

Plants produce dynamic and complex defense mechanisms including enzymes to avoid the insect damages. One compound used in the plant defense systems is a trypsin inhibitor, which reduces the activity of trypsin and other proteases. Therefore, it reduces the amino acid bioavailability in many organisms, including humans (Becker-Ritt et al. 2004). This kind of inhibitors are mainly found in the seeds and grains of leguminous plants and besides their importance to human nutrition, they modulate process into and out of the cell, interfere with the storage of nitrogen and act as defense compounds against herbivorous, pests, parasites and pathogens (Vasconcelos et al. 1994; Carlini and Grossi-de-As 2002; Follmer and Carlini 2005). These inhibitors have also been related with other biological activities such as the control of proteolysis in vitro cell cultures (Clawson 1996) and reduction of carcinogenic processes (Kennedy 1995 and 1998; Kobayashi et al. 2004).

There are four commercial sources of trypsin inhibitors with different molecular weight and inhibitory power (times weight): Lima beans (8-10 $\mathrm{kDa}$; 2.2); Bovine pancreas (6.5 $\mathrm{kDa} ; 2.5)$; ovomucoid (8-10 kDa; 1.2) and soybeans (20.7 $22.3 \mathrm{kDa} ; 1.2)$. Soybeans contain several inhibitors, but the Kunitz inhibitor (STI) is considered to be the primary one. All of them inhibit the chymotrypsin to a lesser extent compared to trypsin and the Kunitz inhibitor has been shown to be the best pancreatic inhibitor (Carlini and Grosso-de-As 2002; Becker-Ritt et al. 2004). Soybean (Glycine max (L) Merril) seeds are known to contain different proteins displaying nutritional, antinutritional and/or toxic effects, such as soybean agglutinin (as Nacetylgalactosamine-specific lectin), proteinase inhibitors (Kunitz and Bowman-Birk type's trypsin and chymotrypsin inhibitors) and urease (seed and tissue isoforms). Two other toxic proteins were previously isolated from soybean, soyatoxin (21 kDa) (Vasconcelos et al. 1994) and soybean toxin $(18.4 \mathrm{kDa})$ which were immunologically related to canatoxin, a toxic protein from Canavalia ensiformis (jackbean) seeds (Becker-Ritt et al. 2004). Aggregation of jackbean urease (JBU) is associated with the alterations of its biological properties, notably the ureolytic and entomotoxic activities. Studies have shown an influence of metal ions on protein oligomerization. In addition, $\mathrm{Cu}$ (II) induces the inhibition of both ureolytic and insecticidal activities of JBU (Follmer and Carlini 2005).

Other studies using mixtures and combination of pesticides and metal ions showed synergistic lethal effects in the marine microcrustacean Tigriopus brevicornis (Müller). Using sublethals levels, the presence of metal ions enhances the inhibitory effects of the insecticides (Forget et al. 2005). Rayms-Keller et al. (1998) evaluated the effect of heavy metals on Ae. aegypti (Culicidae) larvae. Studies were conducted to determine the biological effects of heavy metals on the development of Ae. aegypti. Embryos immersed in $32 \mathrm{ppm} \mathrm{Cu}$ (II) or 5 ppm Cd(II) did not hatch. The arrest of hatching was in part reversible by the removal of the heavy metals. The mortality rate of third-instar larvae exposed to heavy metals for 24 $\mathrm{h}$ was metal- and dose- dependent; the $50 \%$ lethal concentration $\left(\mathrm{LC}_{50}\right)$ endpoints were $3.1,16.5$, and $33 \mathrm{ppm}$ for $\mathrm{Hg}(\mathrm{II}), \mathrm{Cd}(\mathrm{II})$, and $\mathrm{Cu}(\mathrm{II})$, respectively. Interestingly, a proportion of $A e$. aegypti third-instar larvae exposed to either $\mathrm{Cu}(\mathrm{II})$ or Cd(II) for $24 \mathrm{~h}$ failed to produce a dissectable peritrophic matrix. This failure to produce a dissectable peritrophic matrix also was metal- and dose-dependent. These results have been discussed in the context of Ae. aegypti as a model system for investigating the molecular biological effects of heavy metals in aquatic insects. Servia et al. (2006) demonstrated that when spiked in sediments, $\mathrm{Cu}$ (II) was known to reduce the growth of Chironomus riparius larvae and the production of eggs by the adult females. C. riparius larvae were exposed to nominal concentrations of copper of $0,6.5,12.5,25$ and $50 \mathrm{mg} \cdot \mathrm{kg}^{-1}$ of dry sediment (silica). The increase in the concentration of copper resulted in an increasing delay in larval growth in both the sexes. Desynchronized development was observed, as shown by the increase in the number of individuals that remained in the third instar or early phases of the fourth instar, as well as by a reduction in age of males. Concerning the energy reserves, the levels of sugars (glycogen, trehalose and glucose) in the dissected larvae remained almost constant among levels of exposure. In contrast, at the highest copper concentration $\left(50 \mathrm{mg} \cdot \mathrm{kg}^{-1}\right)$, triglyceride levels suffered a slight reduction whereas the level of free glycerol significantly increased. It was concluded that the selection of $C$. riparius larvae for both sex and age improved the relevance of 
some energy-yielding substrates such as the indicators of adverse physiological effects of copper in free form and as complexes.

Many studies have reported toxic and carcinogenic effects induced when humans and animals are exposed to certain metals. It is also known that several essential transition metals, such as zinc, iron, copper, cobalt and manganese participate in the control of various metabolic and signaling pathways. However, their rich coordination chemistry and redox properties allow them to escape the control mechanism such as homeostasis, transport, compartmentalization and binding to designated tissue and cell constituents. The breakdown of these mechanisms can lead to the binding of the metal ions to the proteins other than those tailored for that purpose or displacement of others metal ions from their natural binding sites. An increasing set of data provides evidence that toxic and carcinogenic metals are capable to interact with nuclear proteins and DNA causing oxidative deterioration of biological macromolecules (Valko et al. 2005). The oxidative nature of metal-induced genotoxic damage has been provided by the detailed studies showing that metals (iron, copper, cadmium, chromium, mercury, nickel, vanadium, cobalt and others) possess the ability to produce the reactive radicals resulting in DNA damage, lipid peroxidation, depletetion of protein sulfhdryls and others effects. Reactive radical species include a wide range of oxygen-, carbon-, sulfur-radicals, originating from superoxide, hydrogen peroxide, and lipid peroxides. The toxic effects of metal ions include hepatotoxicity, neurotoxicity and nephrotoxicity (Stohs and Bagchi 1995). Yasuke et al. (1995) showed that metal-mediated oxidative damage to cellular and isolated DNA by certain tryptophan metabolites. These results suggested that in the presence of $\mathrm{Mn}(\mathrm{II})$ or $\mathrm{Cu}(\mathrm{II})$, these tryptophan metabolites produced $\mathrm{H}_{2} \mathrm{O}_{2}$ and/or free radicals which were activated by the transition metal ion to cause damage to DNA, both in the case of isolated DNA and cultured cells.

A probable detoxification protein in Ae. aegypti was identified by Qian et al (2002), which described the functional characterization of a specific mosquito transaminase $(42.5 \mathrm{kDa}$; SDS/PAGE) responsible for catalyzing the transamination of 3-hydroxykynurenine (3-HK) to xanthurenic acid (XA). The enzyme was purified from Ae. aegypti larvae by ammonium sulfate fractionation, heat treatment, and various chromatographic techniques, plus non-denaturing electrophoresis. Northern analysis showed the active transcription of the enzyme in larvae and developing eggs. Substrate specificity analysis of this mosquito transaminase demonstrated that the enzyme was active with 3-HK, kynurenine, or alanine substrates. The biochemical characteristics of the enzyme in conjunction with the profiles of 3-HK transaminase activity and XA accumulation during mosquito development clearly pointed out its physiological function in the 3-HK to XA pathway. The results of the study suggested that the mosquito transaminase was evolved in a manner precisely reflecting the physiological requirement of detoxifying $3-\mathrm{HK}$ produced in the tryptophan oxidation pathway in the mosquito.

Aminopolycarboxylic acids, which include ethylenediaminetetraacetic acid (EDTA), nitrilotriacetic acid (NTA), diethylene-triaminepentaacetic acid (DTPA), 1.3-propylene-diaminetetraacetic acid (1.3-PDTA), $\beta$-alaninediacetic acid $(\beta$-ADA), and methylglycinediacetic acid (MGDA), constitute a class of complexing agents that occur in a wide range of domestic products and that are used intensively as metal sequestrants in several industrial applications. Because they are highly polar and partially nondegradable, aminopolycarboxylates are released into the aquatic environment in significant quantities, mainly via wastewater. This review summarizes the available data and information on the eutrophication potential and toxicity of aminopolycarboxylates to a multitude of aquatic organisms including vertebrates, invertebrates, algae, bacteria, and protozoa. The ecotoxic effects of aminopolycarboxylates are dependent on their speciation that is on their presence in a free or a metal-complexed form. Aminopolycarboxylate toxicity is influenced by water hardness, chemical speciation, and $\mathrm{pH}$ (Carsten and Schmidt 2004).

The objective of this work was to evaluate the toxicity of salts $\mathrm{Co}(\mathrm{II}), \mathrm{Ni}(\mathrm{II})$ and $\mathrm{Cu}(\mathrm{II}), \mathrm{STI}$ (soybean trypsin inhibitor, Kunitz type; $20.7 \mathrm{kDa}$ ), $\mathrm{Na}_{2}$ [EDTA-Cu(II)] and sodium acrylic polymer (SAP) on Ae aegypti and A. salina larvae. New actives were evaluated in a different way from synthetic pesticides (organochlorides, organophosphorates, carbamates, and pyrethroids) which owns toxicity based on the inhibition and/or neurotoxicity. The new actives produce the death of the insect by physical damages disorganizing 
the perithrophic matrix in the digestive system of the insect through the production of free radical and/or the oxidizing species. This way, $\mathrm{Cu}$ (II) and $\mathrm{Na}_{2}[$ EDTA-Cu(II)] were proposed as actives larvicides, supported in acrylic polymer to slow the release and persistent of active in the reproduction microenvironment for the reproductive control of the Ae. aegypti.

\section{MATERIALS AND METHODS}

$\mathrm{Co}(\mathrm{II}), \mathrm{Ni}(\mathrm{II})$ and $\mathrm{Cu}(\mathrm{II})$ salts were purchased from Synth/ACS, Brazil and DMSO from Carlos Erba, Italy. EDTA dissodium salt was from Merck, Germany and the Trypsin inhibitor type I$\mathrm{S}$ (Kunitz type) from soybean and the acrylic polymers were from Sigma-Aldrich Co, St. Louis, Mo, USA). All chemicals were of reagent grade.

\section{Bioassays with Ae. aegypti and A. salina}

The toxicity assays were carried out with $A e$. aegypti third-instar $\left(3^{\text {th }}\right)$ larvae from the eggs collected after 2 to 3 months and kept with blood feeding at $25-30^{\circ} \mathrm{C}$ with $\mathrm{pH}$ being near to acidic to neutrality. Hydrated salts of $\mathrm{Co}\left(\mathrm{NO}_{3}\right)_{2} \cdot 6 \mathrm{H}_{2} \mathrm{O}$, $\mathrm{Ni}\left(\mathrm{NO}_{3}\right)_{2} \cdot 6 \mathrm{H}_{2} \mathrm{O}$ and $\mathrm{CuSO}_{4} \cdot 5 \mathrm{H}_{2} \mathrm{O}$, acrylic polymer (SAP), $\mathrm{Na}_{4}$ EDTA, STI, and their combinations were dissolved in aqueous dimethyl sulfoxide (DMSO) $\left(0.1 \mathrm{mg} \mathrm{L}^{-1}\right)$ in a final concentration of $1.0,0.5,0.25,0.125,0.062,0.030$ and $0.015 \mathrm{mg}$ $\mathrm{mL}^{-1}$. The larvae were picked up with a disposable Pasteur pipette and put on a nylon frame to remove the excess of water. Then 25 larvae were distributed in $25 \mathrm{~mL}$ of each solution to be tested. A solution of $0.1 \mathrm{mg} \mathrm{L}^{-1}$ DMSO was used as a negative control and $0.25 \mathrm{mg} \mathrm{mL}^{-1}$ Rotenone was used as a positive control. The cytotoxic assay was carried out with larvae of the micro crustacean $A$. salina (brine shrimp) from the $2^{\text {th }}$ instar obtained by successive emerging, with partial light and temperature between 22 and $25^{\circ} \mathrm{C}$. The preliminary assays were undertaken in triplicates realized in different days with the following concentrations of salts, $\mathrm{Na}_{4}$ EDTA and STI (the concentrations are missing) in four replicates. The mortality was determined after 24 and $72 \mathrm{~h}$ of exposition of the larvae to the solution to be tested. Larvae which showed no movement after stimulus with a Pasteur pipette were considered dead. The experimental design was completely randomized. $\mathrm{LC}_{10}, \mathrm{LC}_{50}$, and $\mathrm{LC}_{90}$ were determined according to Probist (McLaughlin 1991) with 95\% confidence intervals. The bioassays for LC were realized to A. salina with metals ions, EDTA, STI, $\mathrm{SAP}-\mathrm{Cu}(\mathrm{II}), \quad \mathrm{Na}_{2}[\mathrm{EDTA}-\mathrm{Cu}(\mathrm{II})]$, and SAP$\mathrm{Na}_{2}$ [EDTA-Cu(II)]. However, the lethal concentrations could not be calculated for SAP$\mathrm{Cu}$ (II) and SAP-Na $a_{2}[\mathrm{EDTA}-\mathrm{Cu}(\mathrm{II})]$ due to the increase of the viscosity from the water enviroment, salinity change and the indisposition of the water by the acrylic polymer which possibly contributed to the total mortality of A. salina.

\section{RESULTS AND DISCUSSION}

The bioassays of the isolated and combinations of compounds were performed. The isolated compounds and their combinations resulted in significant differences in mortality of Ae. aegypti and A. salina larvae (Table 1 ).

Table 1 - Lethal Concentration (LC; mg. $\mathrm{L}^{-1}$ ) for mortality of $10 \%, 50 \%$ and $90 \%$ of Aedes aegypti $3^{\text {th }}$ instar larvae and Artemia salina $2^{\text {th }}$ instar larvae treated with salts of metals ions, EDTA, STI, EDTA - Me(II), and acrylic polymer (SAP)

\begin{tabular}{|c|c|c|c|c|c|c|}
\hline \multirow[b]{2}{*}{ Treatments } & \multicolumn{3}{|c|}{ Ae. aegypti (mg. $\left.\mathrm{L}^{-1}\right)$} & \multicolumn{3}{|c|}{ A. salina $\left(\mathrm{mg} . \mathrm{L}^{-1}\right)$} \\
\hline & $\mathbf{L C}_{10}$ & $\mathbf{L C}_{50}$ & $\mathrm{LC}_{90}$ & $\mathbf{L C}_{10}$ & $\mathrm{LC}_{50}$ & $\mathrm{LC}_{90}$ \\
\hline $\mathrm{Co}(\mathrm{II})$ & 0.00 & 0.00 & 0.00 & 0.00 & 0.00 & 0.00 \\
\hline $\mathrm{Ni}(\mathrm{II})$ & 0.00 & 0.00 & 0.00 & 0.00 & 0.00 & 0.00 \\
\hline $\mathrm{Cu}(\mathrm{II})$ & 5.45 & 182.05 & 541.24 & $(*)$ & $(*)$ & $(*)$ \\
\hline $\mathrm{Co}(\mathrm{II})$ plus $\mathrm{Ni}$ (II) plus $\mathrm{Cu}$ (II) & $(*)$ & $(*)$ & $(*)$ & 7.69 & 52.22 & 354.51 \\
\hline $\mathrm{Na}_{4}$ EDTA & 0.00 & 0.00 & 0.00 & 8.22 & 623.61 & $1,759.67$ \\
\hline STI & 0.00 & 0.00 & 0.00 & 1.69 & 283.15 & 1.132 .57 \\
\hline $\mathrm{Na}_{2}[$ EDTA-Cu(II)] & 5.26 & 32.65 & 127.50 & 37.17 & 73.20 & 144.16 \\
\hline $\mathrm{Na}_{4}$ EDTA plus STI & 0.00 & 0.00 & 0.00 & 0.00 & 0.00 & 0.00 \\
\hline STI plus $\mathrm{Na}_{2}[$ EDTA-Cu(II)] & $(*)$ & $(*)$ & $(*)$ & 29.84 & 64.21 & 138.18 \\
\hline SAP plus $\mathrm{Cu}(\mathrm{II})$ & $(* *)$ & $(* *)$ & $(* *)$ & $(* *)$ & $(* *)$ & $(* *)$ \\
\hline SAP plus $\mathrm{Na}_{2}$ [EDTA-Cu(II)] & $(* *)$ & $(* *)$ & $(* *)$ & $(* *)$ & $(* *)$ & $(* *)$ \\
\hline
\end{tabular}


Metals ions $\mathrm{Co}(\mathrm{II}), \mathrm{Ni}(\mathrm{II}), \mathrm{Na}_{4}$ EDTA and STI, as well as the combination of $\mathrm{Na}_{4}$ EDTA and STI had no toxic effect on the larvae of Ae. aegypti (see Table 1). In addition, A. salina larvae were not affected by the treatment with isolated $\mathrm{Co}$ (II), $\mathrm{Ni}(\mathrm{II})$, and a combination of $\mathrm{Na}_{4}$ EDTA and STI. The concentrations observed to reach $\mathrm{LC}_{90}$ for $A$. salina were low, with the exception of isolated $\mathrm{Na}_{4}$ EDTA and STI. This result was expected due the mitotic phase of this brine shrimp and/or in cases, in which the alkali salt $\mathrm{Na}_{4}$ EDTA was present, toxic effects were most often related to metal deficiencies caused by the complexation of essential trace elements and/or protease-inhibitors (STI) completely inhibited the proteases activity. These results together with previous data showing $\mathrm{Cu}$ (II) and $\mathrm{Hg}$ (II) to be potent inhibitors of the enzyme suggested that the $A$. cytosol protease was a thiol protease. The cytosol protease in artemia plays a central role in yolk platelet utilization and protein synthesis regulation during the development (Warner and Shridhar 1980; Warner and Shridhar 1985).

The combination of $\mathrm{Na}_{4}$ EDTA and STI with metals ions seemed to reduce the toxic effect on $A$. salina $\left(61.24 \mathrm{mg} \cdot \mathrm{L}^{-1}, \quad \mathrm{LC}_{50}\right)$. These results suggested a possible use of these compounds, complexes and combinations to control of Ae. aegypti and to minimize the toxic effects for no target organisms by the slow release of the active metal ion or $\mathrm{Na}_{2}$ [EDTA-Cu(II)] by the polymer matrix. On the other hand, the combination of acrylic polymers, $\mathrm{Na}_{2}$ [EDTA-Cu(II)] seemed to enhance the toxic effect on Ae. aegypti larvae. The polymeric matrix may contain the actives in the encapsulated form, protecting the contact with no target organisms and liberating the actives in a controlled way for the water and aquatic environment that constitutes the reproduction way of the Ae. aegypti. It's interesting to note that the slow release depends on the concentration and the temperature. The concentration in the liquid environment is kept according to the temperature and this higher concentration of actives will be coincident with the peeks of reproduction and the cycles of reproduction of the Ae. aegypti that usually occurs in the environments of high humidity and temperatures. This way, the higher the environmental temperature, the higher will be the liberation of the encapsulated actives and consequently, the lethality for the Ae. aegypti larvae.

Another interesting aspect of the study was that $\mathrm{Cu}(\mathrm{II})$ presented the most toxicity for the $A e$. aegypti (575.75 mg. $\mathrm{L}^{-1} ; \mathrm{LC}_{90}$ ), compared to $\mathrm{Co}$ (II) and $\mathrm{Ni}$ (II) in the bioassays. The combination of the $\mathrm{Cu}$ (II) with $\mathrm{Na}_{4}$ EDTA producing the metal chelate $\mathrm{Na}_{2}$ [EDTA-Cu(II)] reduced the lethal concentration (increase of the toxicity) to the larvae of the Ae. aegypti. of $\mathrm{Cu}(\mathrm{II})$ from 541.24 mg. $\mathrm{L}^{-1} \quad\left(\mathrm{LC}_{90}\right)$ to $127.50 \mathrm{mg} . \mathrm{L}^{-1}\left(\mathrm{LC}_{50}\right)$ for $\mathrm{Na}_{2}$ [EDTA-Cu(II)], which meant that the average was almost five $(5 x)$ times, considering the toxic concentrations of the salts $\mathrm{Cu}$ (II) and $\mathrm{Na}_{2}$ [EDTA$\mathrm{Cu}(\mathrm{II})]$ to reach $\mathrm{LC}_{50}$ and $\mathrm{LC}_{90}$.

The metal chelate $\mathrm{Na}_{2}$ [EDTA-Cu(II)], apparently become more toxic because of the inversion of the positive charge $(+)$ from the free metal ion to the negative charge(-) of the chelate and the presence of the hydrophilic cover by the EDTA molecule, probably due to its own higher capability to transport the complex metal ion and the cellular permeation, inducing a greater metabolic activity in the production of free radicals and the damages through the metabolic stress in the organism of the larvae. The cellular damages and the disaggregation of the perithrofic matrix when observed by histo-pathological images were more intense for the Ae. aegypti at the lower dosages despite the mortality was observed in a longer time. This showed that the toxicity of the actives was quite linked to the metabolism of the larvae (results not showed).

The acrylic polymer when liberating the free metal ion $\mathrm{Cu}$ (II) or metal chelate $\mathrm{Na}_{2}$ [EDTA-Cu(II)] increased gradually the capability of retention of molecules of water and the viscosity of the environment making it inadequate for the reproduction and resulting the mobility of the $A e$. aegypti larvae and the A. salina more difficult. This change in viscosity also caused stress to the organism in the reproduction environment and could contribute to its mortality and a higher ingestion of the actives. This physical difficulty imposed to the larvae, after the exhausting of the actives, might still be used with advantage for the control of insects that needed the liquid environment for their reproduction, such as $A e$. aegypti. 


\section{CONCLUSION}

The results suggested the use of free metal ion $\mathrm{Cu}$ (II), metal chelate $\mathrm{Na}_{2}$ [EDTA-Cu(II)] and slow release matrix SAP-Na $\left.\mathrm{NaDTA}_{2} \mathrm{Cu}(\mathrm{II})\right]$ with actives larvicides. The complex form could enhance the toxicity of metal ion and the polymer matrix could condition the reproductive environment by dynamic balance temperaturedependent and retention of water molecules for the control of Ae. aegypti. The addition of STI (or other protein) to the mixture of $\mathrm{Na}_{4}$ EDTA and $\mathrm{Cu}$ (II) apparently reduced the toxic effect on $A$. salina and the mixture of acrylic polymer and $\mathrm{Na}_{2}[$ EDTA-Cu(II)] improved the lethal effects on Ae. aegypti and guaranteed a persistent effect for the slow liberation in the actives for some reproductive cycles of insect. The importance of these findings for chemical control of Ae. aegypti and toxicity for non-target organism could be the choice of low costs larvicides formulation based in metals ions, chelates, STI and acrylic polymer (SAP). More studies are necessary to establish the conditions of larvicidal activities, slow release of actives, damages to the digestive system of the insects (histo-pathological analysis) and studies about the environmental security, mainly through the phytoremediation and solar degradation to complex of aminopolycarboxylates.

\section{ACKNOWLEDGEMENTS}

The authors wish to thank for the great support and facilities provided by The Pantanal Research Center (CPP); Rede Dengue MS; FUNDECT; PROCAD/CAPES and MCT/CNPq.

\section{REFERENCES}

Autran, E. S.; Neves, I. A.; da Silva, C. S. B.; Santos, G, K. N.; da Câmara, C. A. G. and Navarro, D. M. A. F. (2008), Chemical composition, oviposition deterrentand larvicidal activities against Aedes aegypti of essential oils from Piper marginatum Jacq. (Piperaceae). Bioresource Technology, In Press, Corrected Proof, Available online 12 December 2008.

Becker-Ritt, A. B; Mulinari, F.; Vasconcelos, I. M. and Carlini, C. R. (2004), Antinutritional and/or toxic factors in soybean (Glycine max (L) Merril) seeds: comparison of different cultivars adapted to the southern region of Brazil. J. Sci. Food Agric., 84, 263-270.

Carlini, C. R. and Grossi-de-As, M. F. (2002), Plant toxic proteins with insecticidal properties. A review on their potentialities as bioinsecticides. Toxicon, $\mathbf{4 0}$, $1515-1539$.

Clawson, G. A. (1996), Protease inhibitors and carcinogenesis: a review. Cancer Invest., 14, 597608.

De Omena, M. C.; Navarro, D. M. A. F.; de Paula, J. E.; Luna, J. S.; Ferreira de Lima, M. R. and Sant'Ana, A. E. G. (2007), Larvicidal activities against Aedes aegypti of some Brazilian medicinal plants. Bior. Tech., 98, 2549-2556.

Follmer, C. and Carlini, C. R. (2005), Effect of chemical modification of histidines on the copperinduced oligomerization of jack bean urease (EC 3.5.1.5). Arch. Biochem. Biophys., 435, 15-20.

Forget, J.; Pavillon, J-F.; Beliaeff, B. and Bocquené, G. (2005), Joint action of pollutant combinations (pesticides and metals) on survival (LC50 values) and Acetylcholinesterase activity of Tigriopus Brevicornis (Copepoda, Harpacticoida). Environ. Toxic. Chem., 18, 912-918.

Kennedy, A. R. (1995), The evidence for soybean products as cancer preventive agents. J. Nutri., 125, (Suppl.3): 733s-743s.

Kennedy, A. R. (1998), Chemopreventive agents: protease inhibitors. Pharmacol. Ther., 78, 167-209.

Kobayashi, H.; Yagyu, T.; Inagaki, K.; Kondo, T.; Suzuki, M.; Kanayama, N. and Terao, T. (2004), Therapeutic efficacy of once-daily oral administration of a Kunitz-type protease inhibitor, bikunin, in a mouse model and in human cancer. Cancer, 100, 869-877.

McLaughlin, J. M. (1991), Crown gall tumours on potato discs and brine shrimp lethality: two simple bioassays for higher plant screening and fractionation. In K. Hostettmann, Assays for Bioactivity, Methods in Plant Biochemistry. Academic Press, San Diego, 2-32.

Rayms-Keller, A.; Olson, K. E.; McGaw, M.; Oray, C.; Carlson, J. O. and Beaty, B. J. (1998), Effect of Heavy Metals on Aedes aegypti (Diptera:Culicidae) Larvae. Ecotoxicol. Environ. Saf., 39, 41-47.

Sá, R. A.; Santos, N. D. L.; Borges da Silva, C.S.; Napoleão, T. H.; Gomes, F. S.; Cavada, B. S.; Barroso Coelho, L. C. B.; D. M. A. F.; Bieber, L. W. and Paiva, P. M. G. (2008), Larvicidal activity of lectins from Myracrodruom urundeuva on Aedes aegypti Comparative Biochemistry and Physiology Part C: Toxicol. \& Pharmacol., In Press, Corrected Proof, Available online 15 August 2008.

Schmidt, C. K. and Brauch, H-J. (2004), Impact of aminopolycarboxylates on aquatic organisms and eutrophication: Overview of available data. Environ Toxicol., 19, 620-637. 
Servia, M. J.; Péry, A. R. R.; Heydorff, M.; Garric, J. and Lagadic, L. (2006), Effects of copper on energy metabolism and larval development in the midge Chironomus riparius. Ecotoxicoly, 15, 229-240.

Stohs, S. J. and Bagchi, D. (1995), Oxidative mechanisms in toxicity of metals ions. Free Radic. Biol. Med., 18, 321-336.

Valko, M.; Morris, H. and Cronin, M. T. D. (2005). Metals, toxicity and oxidative stress. Curr. Med. Chem., 12, 1161-1208.

Vasconcelos, I. M.; Trentim; A.; Guimarães, J. A. and Carlini; C. R. (1994), Purification and physicochemical characterization of soyatoxin, a novel toxic protein isolated from soybeans (Glycine max). Arch. Biochem. Biophys., 312, 357-366.

Warner, A. H., and Shridhar, V. (1980), in The Brine Shrimp Artemia (Persoone, G., Sorgeloos, P., Roels, O., and Jaspers, E., eds) vol. 2, p. 355-364, Universa Press, Wetteren, Belgium.

WHO - World Health Organization. (1997), Dengue bulletim: Epidemic dengue/dengue haemorrhagic fever: A global public health problem problem in $21^{\text {st }}$ century. Avaliable at: < http://www.searo.who.int/EN/Section10/Section332/ Section519_2380.htm > Acessed at: 31/12/2008.

World Health Organization. (2001), Dengue / dengue haemorrhagic fever in the Americas. Summary of research and control in the Americas. TDR News, 64, Avaliable at: < http://www.who.int/tdr/publications/ tdrnews/news64/dengue.htm $>$. Acessed at: $31 / 12 / 2008$.
World Health Organization. (2004), Using climate to predict infectious diseases outbreaks: a review. Avaliable at: http://www.who.int/globalchange/publications/en/oeh 0401.pdf > . Acessed at: 31/09/2008.

World Health Organization. (2006), Report on Dengue. Avaliable at: < http://www.who.int/tdr/ publications/publications/swg_dengue_2.htm >. Acessed at: 23/10/2008.

World Health Organization. (2007a), Dengue/DHF. Situation of Dengue / Dengue Haemorrhagic Fever in the South-East Asia Region.Variable endemicity for DF/DHF in countries of SEA Region. Avaliable at: < http://www.searo.who.int/en/Section10/Section332_1 100.htm >. Acessed at: 29/12/2008

World Health Organization. (2007b), Impact of Dengue. Avaliable at: < http://www.who.int/csr/disease/dengue/impact/en/ind ex.html >. Acessed at: 27/12/2008.

World Health Organization. Fiebre amarilla (2008). Avaliable at: <http://www.who.int/topics/ yellow_fever/es/>. Acessed at: 31/12/2008.

Received: March 10, 2008; Revised: January 06, 2009; Accepted: September 03, 2009. 


\section{PÁGINA EM BRANCO}

